\title{
Are children with asthma in South Korea also associated with vitamin $\mathrm{D}$ deficiency?
}

\author{
Yu-Ri Kim ${ }^{1}$, Sung Chul Seo ${ }^{2}$, Young Yoo ${ }^{1,3}$, Ji Tae Choung ${ }^{1,3}$ \\ ${ }^{1}$ Environmental Health Center for Asthma, Korea University Medical Center, Seoul, Korea; ${ }^{2}$ Department of Industrial Health, \\ College of Applied Sciences, Catholic University of Pusan, Busan, Korea; ${ }^{3}$ Department of Pediatrics, Korea University College \\ of Medicine, Seoul, Korea
}

\begin{abstract}
Recently, epidemiologic studies have shown that the lack of serum vitamin D levels may be associated with high asthma prevalence, but its effect is still controversial, depending on season, area, and food consumption. We aimed to examine the association of serum vitamin $D$ levels with the prevalence of pediatric asthma in Korea. A total of 80 children (50 asthmatic children and 30 healthy controls) aged 6-14 years were participated in this study. Serum vitamin D levels were measured and compared between the two groups. Moreover, the relationship of serum vitamin $\mathrm{D}$ levels with results of pulmonary function test and environmental factors (lifestyle habits and residential factors) collected by a questionnaire survey were examined in asthmatic patients. Serum vitamin D levels in asthmatic children $(16.63 \pm 4.20 \mathrm{ng} / \mathrm{mL})$ were significantly lower than that in healthy controls $(24.24 \pm 6.76 \mathrm{ng} / \mathrm{mL})(p<0.05)$. Also, we found that the prevalence of asthma increase to 0.79 -fold (odds ratio, $0.79 ; 95 \%$ confidence interval, 0.71 to $0.88 ; p<0.001$ ) as serum vitamin $D$ level is $1 \mathrm{ng} / \mathrm{mL}$ decreases. The increased time spent in outdoor could affect the increases of serum vitamin D levels significantly. However, no associations of serum vitamin $\mathrm{D}$ with pulmonary function and residential environmental factors (i.e., housing type, living floor, and indoor activity time) were observed. Our findings suggest that serum vitamin $D$ levels were also associated with pediatric asthma in Korea. Moreover, management of serum vitamin $\mathrm{D}$ level in asthmatic children would be a promising approach for preventing exaggeration of their severity.
\end{abstract}

Keywords Vitamin D, Child, Asthma, Serum, Pulmonary function test, Sunlight
Correspondence: Sung Chul Seo Department of Industrial Health, College of Applied Sciences, Catholic University of Pusan, 57 Oryundae-ro, Geumjung-gu, Busan, 46252, Korea

E-mail: sseo@cup.ac.kr

Received: August 2, 2016 Accepted: January 18, 2017 Published: February 14, 2017

This article is available from: http://e-eht.org/

\section{INTRODUCTION}

Asthma is one of the most common allergy-related chronic respiratory illnesses found in children. Although much has been discovered in terms of the condition's pathological physiology, its prevalence has been on a steady rise over the last 20 years [1]. Also, the number of patients with severe asthma as well as the number of patients who experience acute exacerbation such as status asthmaticus, are also on the increase. Continuous much efforts have been invested to unveil the root cause of asthma, and the cause behind its exacerbation. It has been generally understood that both genetic and environmental factors contrib- ute to the condition [1]. Most recently, active research is in progress, which focuses on the potential effects of vitamin $\mathrm{D}$ deficiency in serum, aside from the well-known environmental risk factors such as dust mites, mold, animal allergens, and environmental tobaco smoke. Vitamin D deficiency in serum has been linked with increasing prevalence rate of asthma, as well as atopic dermatitis and allergic rhinitis [2-4]. According to relevant research findings, vitamin $\mathrm{D}$ deficiency in serum has increased among city dwellers, whose exposure to sunlight has decreased over the years of westernized lifestyle. These findings also indicate that asthma tends to be more prevalent in nations with high latitudes [3]. Vitamin D deficiency in serum was 
thought to be eradicated with the fortification of foods and the appearance of rickets. Despite food fortification, multiple studies have shown that vitamin D deficiency in serum is highly prevalent even in sun-related areas of the world and that vitamin D supplementation and fortification of foods in current doses are inadequate to prevent deficiency $[5,6]$. Against this background, it appears that an examination of the potential link between vitamin $\mathrm{D}$ deficiency in serum and asthma symptoms would be useful from the standpoint of prevention and identifying its root causes.

Besides contributing to bone growth and maintenance, vitamin $\mathrm{D}$ is known to play a critical role in the prevention and treatment of osteoporosis as it is an essential hormone required to maintain phosphoric acid and calcium's homeostasis [7]. However, recent epidemiological studies have reported that vitamin $\mathrm{D}$ deficiency in serum may be linked to increased risk of autoimmune disorders and allergy related diseases [7]. Vitamin $\mathrm{D}$ in serum may move into macrophages, dendritic cells, and other immune cells, and binds to intracellular vitamin D receptors and is involved in innate and acquired immunity [8]. In addition, vitamin $\mathrm{D}$ could act directly on antigen presenting cell function and T-cell activation process, regulating the acquired immune response [9]. The lack of serum vitamin $D$, which is involved in the immune function, would lead to immune function disorder [10]. As mentioned above, asthma, is a most common chronic diseases attributed to immune disorder by complex interactions among multiple genetic and environmental factors [4]. Therefore, the complex role of serum vitamin $\mathrm{D}$ level in immune system is regarded all the more important.

Numerous epidemiological studies concerning the root causes of pediatric asthma are reporting the association between vita$\min \mathrm{D}$ deficiency and increased rate of asthma. For instance, according to a study by Bener et al. [11] involving children in Qatar, the level of serum vitamin $\mathrm{D}$ in the asthmatic children was significantly lower than that of the healthy control, and a higher rate of vitamin D deficiency was found in the asthmatic children. Another study involving African Americans reported a significant correlation between vitamin $\mathrm{D}$ deficiency and asthma. A study concerning asthmatic children in North America also reported that vitamin $\mathrm{D}$ deficiency was associated with an increased rate of emergency room visit attribute to asthma symptoms $[12,13]$. Similarly, a study involving asthmatic children in Costa Rica found that low level of vitamin D was associated with an increased level of immunoglobulin E, increased number of eosinocyte, increased hospitalization, increased use of anti-inflammatory medication, and increased bronchial sensitivity [14].

As reviewed so far, vitamin $\mathrm{D}$ deficiency contributes to asthma in children and its exacerbation. Unfortunately, Korean research on this front is sorely lacking, and related studies mostly concern atopic dermatitis [2]. As such, the current study set out to examine the effects of vitamin $\mathrm{D}$ deficiency on pediatric asthma in Korea. Furthermore, we aimed to investigate the potential link between pediatric asthma, serum vitamin D, and environmental factors such as exposure to sunlight.

\section{METHODS}

\section{Study Population}

This study was conducted on 80 children aged 6-14 years recruited from the Allergy Clinic of Korea University Anam Hospital during July to October 2013. Asthmatic children $(n=50)$ were assessed pulmonary-function test, and were determined the diagnosis and severity of asthma, according to the American Thoracic Society criteria. Control subjects $(n=30)$ are a random sample of non-atopic children without any acute or chronic asthma, atopic dermatitis, and allergic rhinitis selected from children who visited a pediatric center. Taking into account the seasonal factors pertaining to vitamin $\mathrm{D}$ exposure, the survey was conducted on the children who visited the hospital between June and October. This study was approved by the institutional review board (IRB) at Korea University Anam Hospital (IRB no. ED12221). Children and their parents provided informed written consent.

\section{Questionnaires}

Factors which can influence pulmonary function, such as sex, exposure to smoking, medication, as well as factors which can influence serum vitamin D synthesis, such as duration of daylight, and length of time spent outdoors were surveyed through the questionnaires.

\section{Serum 25-hydroxyvitamin D Levels}

Blood samples ( $3 \mathrm{~mL}$ of each child) were collected, and serum was separated and stored at $-70^{\circ} \mathrm{C}$ until analysis. Serum 25 -hydroxyvitamin D (hereinafter referred to as "serum vitamin D") were measured using a commercially available kit (IDS Ltd., Boldon, UK). In descriptive analyses, we categorized serum vitamin D levels as deficient $(<20 \mathrm{ng} / \mathrm{mL})$, insufficient (20-30 $\mathrm{ng} / \mathrm{mL}$ ), and sufficient ( $\geq 30 \mathrm{ng} / \mathrm{mL}$ ) based on previous recommendations [15].

\section{Pulmonary-function Test}

Forced expiratory volume in one second $\left(\mathrm{FEV}_{1}\right)$ and forced vital capacity (FVC) were measured using a microspirometer (Microspiro-106 HI 298, Chest, Corporation Tokyo, Japan), in accordance with the recommendations of the American Tho- 
racic Society. FEV 1 and FVC were measured three times for each child and the highest value among the three values was recorded. The values were compared with the reference standard based on predicted values for Korean children. Also, classifications of asthma severity were determined with respect to categorized measures of $\mathrm{FEV}_{1} \%$ predicted ( $>60 \%$ for severe, $60-80 \%$ for moderate, $>80 \%$ for mild) [16].

\section{Statistical Analyses}

Serum vitamin D levels were shown to have normal distributions as determined by the Shapiro-Wilk tests. Median value was calculated to describe the center of the data. Data on serum vitamin $\mathrm{D}$ levels between asthmatic and control groups were statistically analyzed using the Student's $t$-test. Logistic regression analysis was used to assess the relationship between serum vitamin D levels and pulmonary functions including $\mathrm{FEV}_{1}$, $\mathrm{FVC}$, and $\mathrm{FEV}_{1} / \mathrm{FVC}$. Also, multiple regression analysis was performed to evaluate the correlation with serum vitamin D levels and outdoor activity. All data were expressed as mean \pm standard deviation. All data were analyzed using the SAS version 9.1 (SAS Institute Inc., Cary, NC, USA), and a significance level of $5 \%$ was applied unless otherwise indicated.

\section{RESULTS}

\section{Characteristics of Study Subjects}

A total of 80 children participated in the current study, whose ages ranged from 6 to 14 years old. The average age of the healthy group was 9.06 years old, and the corresponding value of the patient group was 11.50 years old. The percentage of boys was greater than that of girls in both groups ( $60 \%$ for control and $64 \%$ for the patient group, respectively) (Table 1 ). The average body mass index of the control group and patient group were 16.2 and 18.3, respectively. The mean $\mathrm{FEV}_{1}(\%)$ and the $\mathrm{FEV}_{1} / \mathrm{FVC}$ (\%) of the patient group were lower than those of control group, respectively, but no statistical difference was observed $(p=0.54 ; p=0.16)$.

Table 1. Characteristics of subjects

\begin{tabular}{lccc}
\hline & \multicolumn{1}{c}{ Control } & Asthmatics & $p$-value \\
\hline Total (male/female) & $30(18 / 12)$ & $50(32 / 18)$ & \\
Age $(\mathrm{yr})$ & $9.06 \pm 3.05$ & $11.50 \pm 3.14$ & 0.16 \\
$\mathrm{BMl}\left(\mathrm{kg} / \mathrm{m}^{2}\right)$ & $16.2 \pm 2.7$ & $18.3 \pm 3.1$ & 0.11 \\
$\mathrm{FEV}_{1}(\%)$ & $91.9 \pm 3.5$ & $87.7 \pm 6.4$ & 0.54 \\
FEV $_{1} / \mathrm{FVC}(\%)$ & $90.1 \pm 5.7$ & $84.8 \pm 4.2$ & 0.16
\end{tabular}

Values are presented as mean \pm standard deviation.

$\mathrm{BMI}$, body mass index; FEV ${ }_{1}$, forced expiratory volume in one second; FVC, forced vital capacity.

\section{Comparison of Serum Vitamin D Levels}

The average serum vitamin D level was $16.3 \pm 4.20 \mathrm{ng} / \mathrm{mL}$ in the patient group, and $24.2 \pm 6.76 \mathrm{ng} / \mathrm{mL}$ in the control group (Figure 1). The serum vitamin $\mathrm{D}$ level of the control group was significantly higher than that of the patient group $(p<0.05)$.

\section{Comparison of Asthma Prevalence by Serum Vitamin D Level}

Results of the serum vitamin D level comparison between the

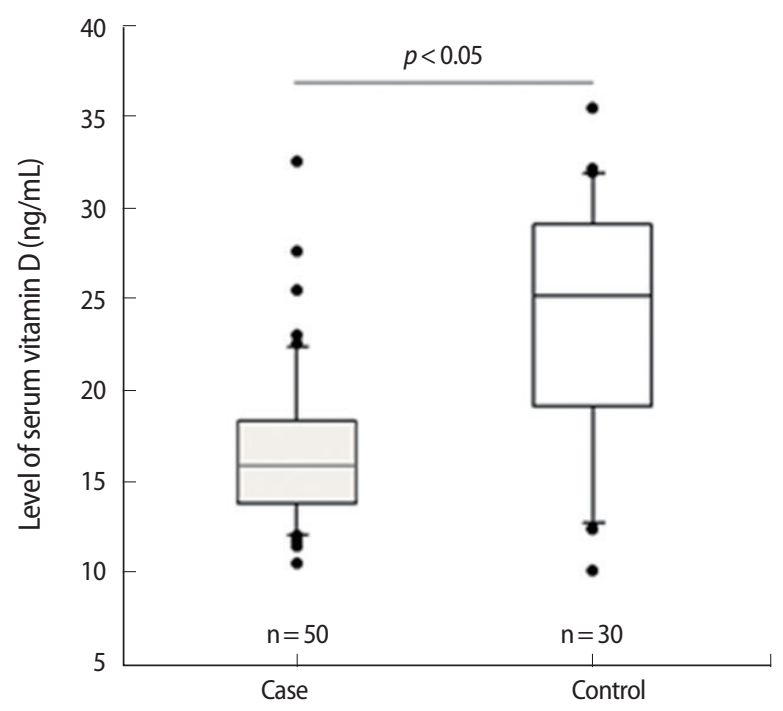

Figure 1. Boxplots of serum vitamin D levels in the asthmatic children ( $\square$ ) and control group $(\square)$. Each boxplot indicates an interquartile range with median, upper, and lower whiskers; upper and lower boundaries (3rd quartile/1st quartile).

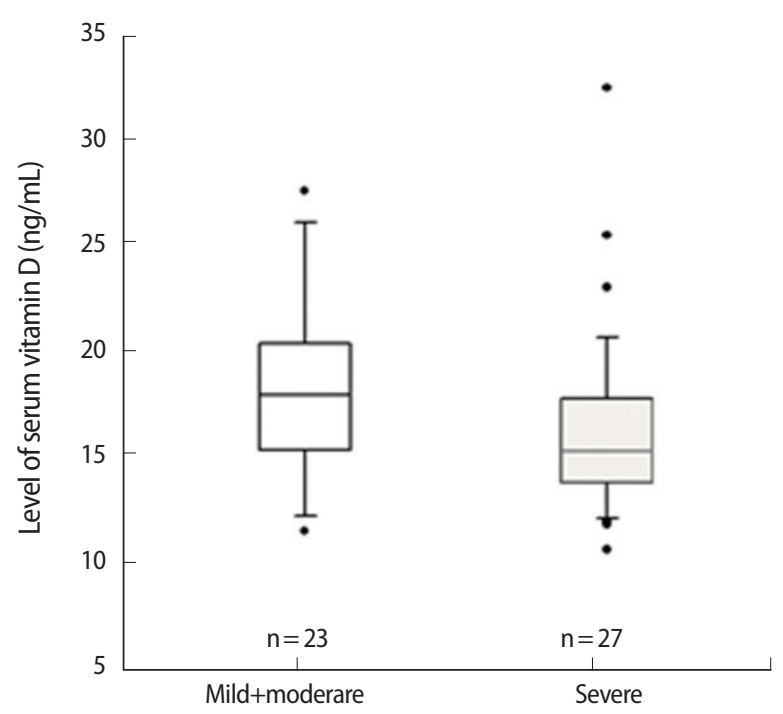

Figure 2. Boxplots for serum vitamin D levels by asthma severity. Severe group and the other group are classified by less and greater than $60 \%$ of the ratio of forced expiratory volume in one second (\%) predicted, respectively. Each boxplot indicates an interquartile range with median, upper, and lower whiskers; upper and lower boundaries (3rd quartile/1st quartile). 
Table 2. Personal variables potentially affecting exposure to sunlight and serum vitamin $D$ level

\begin{tabular}{lccc}
\hline Variable & $\beta$ & $95 \% \mathrm{Cl}$ & $p$-value \\
\hline Age & 0.006 & $-0.42,0.43$ & 0.98 \\
Sex (0: male, 1: female) & 1.179 & $-1.81,4.17$ & 0.43 \\
Group (0: control, 1: case of asthma) & -8.299 & $-11.28,-5.32$ & $<0.001$ \\
Housing type (0: detached, 1: apartment, 2: others) & -0.196 & $-3.45,3.05$ & 0.90 \\
Living floor & 0.161 & $-0.09,0.41$ & 0.20 \\
Sunblock (0: use, 1: not use) & -0.774 & $-4.04,2.50$ & 0.64 \\
\hline
\end{tabular}

$\mathrm{Cl}$, confidence interval.

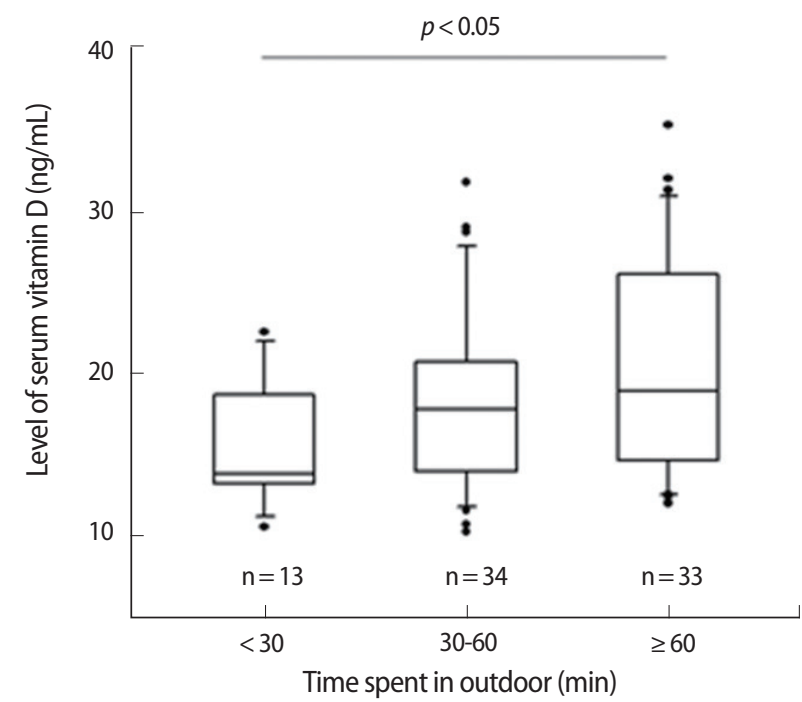

Figure 3. Serum vitamin D levels according to of average time per day spent in outdoor. Each boxplot indicates an interquartile range with median, upper, and lower whiskers; upper and lower boundaries (3rd quartile/1st quartile).

patient group and the control group using $20 \mathrm{ng} / \mathrm{mL}$ as the standard found that $86 \%$ of the children a with sub-standard vitamin D level in serum suffered asthma $(p<0.001)$. The odds ratio according to the serum vitamin $\mathrm{D}$ level was analyzed at 0.79 ( $95 \%$ confidence interval, 0.71 to $0.88 ; p<0.001$ ). The medians of serum vitamin $\mathrm{D}$ levels in each group were $18.4 \mathrm{ng} / \mathrm{mL}$ for mild group, $16.2 \mathrm{ng} / \mathrm{mL}$ for moderate group, and $15.2 \mathrm{ng} / \mathrm{mL}$ for severe group, respectively. In addition, that severe asthma patient group's median value of serum vitamin $\mathrm{D}(15.2 \mathrm{ng} / \mathrm{mL})$ was lower than that of the mild/moderate asthma patient group $(17.9 \mathrm{ng} / \mathrm{mL}$ ) (the numbers of patients in each group were 5 for mild group, 18 for moderate group, and 27 for sever group, respectively). However, the difference was not statistically significant $(p=0.17)$ (Figure 2).

\section{Correlation Between Serum Vitamin D Level and Time Spent in Outdoor}

Lifestyle habits and residential environment factors pertaining to exposure to sunlight, such as housing type, floor of residence, time spent indoors/outdoors were surveyed (Table 2). Results of the serum vitamin D level analysis conducted with $1 \mathrm{hr} / \mathrm{d}$ spent in outdoor as a baseline, found that the average serum vitamin $\mathrm{D}$ level of children who spent less than an hour a day outdoors was lower $(17.9 \pm 5.5 \mathrm{ng} / \mathrm{mL})$ than that of their counterparts who spent an hour or more a day outdoors (21.4 $\pm 7.1 \mathrm{ng} /$ $\mathrm{mL}$ ). Especially, the differences in serum vitamin $\mathrm{D}$ levels between the children who spent less than 30 minutes a day outdoors and those who spent more than an hour a day in outdoor was statistically significant $(p<0.05)$ (Figure 3$)$. However, no statistically significant associations were found in terms of housing type, floor of residence, and the length of time spent indoors.

\section{DISCUSSION}

In this study, we observed that the serum vitamin $\mathrm{D}$ level in asthmatic children was significantly lower than that in nonatopic children. These results are very consistent with those of numerous existing epidemiological researches which examined the association between serum vitamin $\mathrm{D}$ level and the risk of developing asthma [17]. For example, Alyasin et al. [18] reported that the serum vitamin $\mathrm{D}$ level in the healthy controls was significantly higher than that of the asthmatic children, indicating that serum vitamin $\mathrm{D}$ level and asthmatic state were correlated. Another study showed that children with asthma had a significantly lower level of serum vitamin $\mathrm{D}$ than non-atopic children, and that a majority of asthmatic patients (68.1\%) exhibited vitamin $\mathrm{D}$ deficiency in serum [11]. The current study also found that $86 \%$ of the asthmatic children, as well as $28 \%$ of the non-atopic children had a level below the standard $(20 \mathrm{ng} / \mathrm{mL})$. Similarly, Freishtat et al. [12] found that $86 \%$ of the asthmatic children showed vitamin $\mathrm{D}$ deficiency in serum. whereas only $19 \%$ of the non-atopic children exhibited deficiency. A study by Litonjua and Weiss [19] also confirmed that children with vitamin $\mathrm{D}$ deficiency in serum. were at a greater risk of severe asthma attack. Ginde et al. [20] reported that a low level of serum vitamin $\mathrm{D}$ was associated with a higher frequency of respiratory tract infection and a more severe asthma. It is widely known that vitamin $\mathrm{D}$ plays a key role in host immune function which guards 
against infection. Vitamin D's immune regulatory function occurs in various cells including macrophagocytes and dendritic cells [21]. In terms of congenital immunity, vitamin $\mathrm{D}$ promotes the synthesis of antimicrobial peptide. It is also known that vitamin $\mathrm{D}$ influences the function of antigen presenting cells by modulating T-cell activation [22]. In fact, vitamin D is known to suppress Th1 cytokine, such as CD4+ T-cells, interleukin (IL)2 , granulocyte macrophage colony stimulating factor, and interferon-gamma $[23,24]$. Additionally, vitamin $\mathrm{D}$ is known to suppress dendritic cells' $\mathrm{Ox} 40 \mathrm{~L}$ which concerns $\mathrm{Th} 2 \mathrm{immune}$ reaction, thereby promoting proliferation of transforming growth factor- $\beta$ regulatory T-cells [25]. The results of various observational studies indicate that vitamin D's immune regulatory function is linked to asthma and its severity. Considering our findings and results from many studies supporting the link between insufficient serum vitamin $\mathrm{D}$ level and pediatric asthma, it has been suggested that lower level of serum vitamin $\mathrm{D}$ is also associated with the increased asthma prevalence in Korea. Moreover, this study is first to explore the relationship of serum vitamin D level with childhood asthma in Korea, to our knowledge.

Much has been discovered in terms of the link between pulmonary diseases such as asthma and tuberculosis and serum vitamin D. However, its association with pulmonary function has not been clarified [20,26-28]. The current study was not able to find a meaningful association between the serum vitamin $\mathrm{D}$ lev$\mathrm{el}$ in asthmatic children and pulmonary function $\left(\mathrm{FEV}_{1}, \mathrm{FVC}\right.$, $\mathrm{FEV}_{1} / \mathrm{FVC}$ ). Similarly, there has been a study which found a low level of serum vitamin $D$ in asthmatic children, but failed to find a correlation with pulmonary function $[13,14,29]$. A recent study involving Costa Rican children between the ages of 6 and 14 found that vitamin $\mathrm{D}$ deficiency in serum. was not correlated with $\mathrm{FEV}_{1}$ or $\mathrm{FEV}_{1} / \mathrm{FVC}$. In an adult study by Shaheen et al. [28], no significant correlation was also found between serum vitamin $\mathrm{D}$ and pulmonary function. In contrast, Black and Scragg [26] and Choi et al. [27] reported that a low level of serum vitamin $\mathrm{D}$ was associated with low $\mathrm{FEV}_{1}$ and $\mathrm{FVC}$. As seen so far, research results on the association between serum vitamin D and pulmonary function are inconclusive. Rather, the finding appears to suggest that a low level of serum vitamin $\mathrm{D}$ does not affect the structural characteristics of the lungs in the process, while it exacerbate existing asthma symptoms [13]. In addition, the residential area of participants in other studies may recently be suggested one of factors affecting the association between serum vitamin D and pulmonary function. For instance, the associations of serum vitamin D level with pulmonary function were observed in most studies including subjects who live in many different locations, but a contrasting result was reported in the study which recruited the participants within the same residential area [9]. All subjects in this study were also recruited in one particular area (Seoul, Korea), which may affect the analysis of these association, but further research could be necessary.

Upon an analysis of the serum vitamin D levels of asthmatic children $(16.3 \mathrm{ng} / \mathrm{mL})$ and non-atopic children $(24.2 \mathrm{ng} / \mathrm{mL})$, it was observed that both groups of children had vitamin D deficiency in serum and insufficiency, respectively. Compared with the average serum vitamin D levels reported by the National Health and Nutrition Examination Survey of the US (22.08 ng/ $\mathrm{mL}$ ) [30], and the Canadian Health Measures Survey (27.08 $\mathrm{ng} / \mathrm{mL}$ ) [31], the Korean average was lower, measuring at a mere $20.55 \mathrm{ng} / \mathrm{mL}$. Furthermore, Hilger et al. [32] reported that children and teenagers exhibit a significantly lower level of serum vitamin $\mathrm{D}$ adults in many Asian-Pacific countries. According to a vitamin D status study conducted across all age groups in Korea, serum vitamin $\mathrm{D}$ level of individuals between the ages of 10-19 was less than $20 \mathrm{ng} / \mathrm{mL}$. The level starts to increase in individuals over the age of 30 years, with the highest level observed in those in the 60-69 years age bracket [33]. This is attributable to the changes in lifestyle typically observed in many Korean school-aged children, whose time spent outdoors drastically decreases as they enter school and start focusing on academics [2].

Serum vitamin $\mathrm{D}$ level is influenced by the amount of melanine, age, body fat, latitude, season, the length of time spent outdoors, and use of sunscreen since serum vitamin $\mathrm{D}$ is synthesized through the skin's exposure to ultraviolet ray [34]. For this reason, the current study examined housing type, floor of residence, time spent indoors/outdoors, etc. in an effort to identify the influence of sunlight on pediatric asthma. However, there was no significant association of serum vitamin $\mathrm{D}$ level with other environmental factors, except for exposure to sunlight. Our findings showed that greater exposure to sunlight could contribute to increase the serum vitamin D. Recent studies have also found that children with asthma not only have less exposure to sunlight, but they are also less physically active. Upon examination of all the above factors, it was found that the amount of time spent outdoors had an effect on serum vitamin D level. Also, reverse causality may be expected. Namely, asthmatics may tend to stay in indoor since they could avoid environmental factors (i.e., Asian dust, particular matters, pollen) in outdoor. For this reason, they may have low level of serum vitamin $\mathrm{D}$ relatively.

Our findings indicate that the serum vitamin $\mathrm{D}$ level in children with asthma was lower than that of non-atopic children, and that insufficient level of serum vitamin $\mathrm{D}$ increased the risk of developing asthma in children. In addition, increased exposure to sunlight related to the serum vitamin D level could con- 
tribute to lower asthma prevalence. We believe that small sample size of control group relatively is still a limitation of the present study, but it is almost first study for exploring the association of serum vitamin D levels with asthmatic children in Korea, to our knowledge. Information of usage for vitamin D supplements have not been collected in this study. Vitamin D supplements could be associated with the level of serum vitamin D. Rather, we may not assume that children with asthma have not taken the vitamin D supplements relatively, and so the serum vitamin D level was lower than that of control group. Similarly, revere assumption may be expected as well. Thus, more cautious consideration is necessary. More comprehensive research for exploring the causal relationship with serum vitamin D level with asthma would still be necessary. Management of serum vitamin D level in asthmatic children in Korea would also be a promising approach for preventing exaggeration of their severity.

\section{ACKNOWLEDGEMENTS}

This research was supported by the Research Program through the Environmental Health Center for Asthma funded by Ministry of Environment, Republic of Korea. This support is greatly appreciated. We are also grateful to all of the participating children and other individuals involved in our study.

\section{CONFLICT OF INTEREST}

The authors have no conflicts of interest associated with the material presented in this paper.

\section{ORCID}

Yu-Ri Kim http://orcid.org/0000-0003-1286-4271

Sung Chul Seo http://orcid.org/0000-0001-8301-6355

Young Yoo http://orcid.org/0000-0003-3354-6969

Ji Tae Choung http://orcid.org/0000-0003-0432-4048

\section{REFERENCES}

1. Robertson CF, Roberts MF, Kappers JH. Asthma prevalence in Melbourne schoolchildren: have we reached the peak? Med J Aust 2004;180(6):273-276.

2. Shin YH, ParkJH, Sung MS, Kim SW. Correlation between serum 25-hydroxyvitamin D levels and severity of atopic dermatitis in children. Allergy Asthma Respir Dis 2014;2(2):114-121 (Korean).

3. Ginde AA, Liu MC, Camargo CA Jr. Demographic differences and trends of vitamin D insufficiency in the US population, 1988-2004. Arch Intern Med 2009;169(6):626-632.

4. Lange NE, Litonjua A, Hawrylowicz CM, Weiss S. Vitamin D, the immune system and asthma. Expert Rev Clin Immunol 2009;5(6): 693-702.

5. Bischoff-Ferrari HA, Giovannucci E, Willett WC, Dietrich T, Dawson-Hughes B. Estimation of optimal serum concentrations of 25-hydroxyvitamin D for multiple health outcomes. Am J Clin Nutr 2006;84(1):18-28.

6. Binkley N, Novotny R, Krueger D, Kawahara T, Daida YG, Lensmeyer $\mathrm{G}$, et al. Low vitamin $\mathrm{D}$ status despite abundant sun exposure. J Clin Endocrinol Metab 2007;92(6):2130-2135.

7. Lai YH, Fang TC. The pleiotropic effect of vitamin D. ISRN Nephrol 2013;2013:898125.

8. BaekJU, Hwangbo JW, Lee HR, Lee SY. Vitamin D insufficiency is associated with food sensitization in children under 2 years with atopic dermatitis. Allergy Asthma Respir Dis 2013;1(3):211-215 (Korean).

9. Kim YW, Ryu DS, Lee JS. Relationship between serum 25-hydroxyvitamin D and lung function among Korean adults. Allergy Asthma Respir Dis 2015;3(1):35-39 (Korean).

10. Jung JW, Kang HR. Evaluation of vitamin D in patients with asthma. Allergy Asthma Respir Dis 2016;4(1):1-3 (Korean).

11. Bener A, Ehlayel MS, Tulic MK, Hamid Q. Vitamin D deficiency as a strong predictor of asthma in children. Int Arch Allergy Immunol 2012;157(2):168-175.

12. Freishtat RJ, Iqbal SF, Pillai DK, Klein CJ, Ryan LM, Benton AS, et al. High prevalence of vitamin $\mathrm{D}$ deficiency among inner-city African American youth with asthma in Washington, DC. J Pediatr 2010;156(6):948-952.

13. Brehm JM, Schuemann B, Fuhlbrigge AL, Hollis BW, Strunk RC, Zeiger RS, et al. Serum vitamin D levels and severe asthma exacerbations in the Childhood Asthma Management Program study. J Allergy Clin Immunol 2010;126(1):52-58.e5.

14. Brehm JM, Celedón JC, Soto-Quiros ME, Avila L, Hunninghake GM, Forno E, et al. Serum vitamin D levels and markers of severity of childhood asthma in Costa Rica. Am J Respir Crit Care Med 2009;179(9):765-771.

15. Vieth R, Bischoff-Ferrari H, Boucher BJ, Dawson-Hughes B, Garland CF, Heaney RP, et al. The urgent need to recommend an intake of vitamin D that is effective. Am J Clin Nutr 2007;85(3):649650.

16. Bacharier LB, Strunk RC, Mauger D, White D, Lemanske RF Jr, Sorkness CA. Classifying asthma severity in children: mismatch between symptoms, medication use, and lung function. Am J Respir Crit Care Med 2004;170(4):426-432.

17. Litonjua AA. Vitamin D deficiency as a risk factor for childhood allergic disease and asthma. Curr Opin Allergy Clin Immunol 2012;12(2):179-185.

18. Alyasin S, Momen T, Kashef S, Alipour A, Amin R. The relationship between serum 25 hydroxy vitamin d levels and asthma in children. Allergy Asthma Immunol Res 2011;3(4):251-255.

19. Litonjua AA, Weiss ST. Is vitamin D deficiency to blame for the asthma epidemic? J Allergy Clin Immunol 2007;120(5):10311035.

20. Ginde AA, Mansbach JM, Camargo CA Jr. Association between serum 25-hydroxyvitamin $\mathrm{D}$ level and upper respiratory tract infection in the Third National Health and Nutrition Examination Survey. Arch Intern Med 2009; 169(4):384-390. 
21. Adorini L, Penna G, Giarratana N, Roncari A, Amuchastegui S, Daniel KC, et al. Dendritic cells as key targets for immunomodulation by Vitamin D receptor ligands. J Steroid Biochem Mol Biol 2004;89-90(1-5):437-441.

22. Schwalfenberg GK. A review of the critical role of vitamin $D$ in the functioning of the immune system and the clinical implications of vitamin D deficiency. Mol Nutr Food Res 2011;55(1):96-108.

23. Iho S, Kura F, Sugiyama H, Takahashi T, Hoshino T. The role of monocytes in the suppression of PHA-induced proliferation and IL 2 production of human mononuclear cells by 1,25-dihydroxyvitamin D3. Immunol Lett 1985;11(5-6):331-336.

24. Reichel H, Koeffler HP, Tobler A, Norman AW. 1 alpha,25-Dihydroxyvitamin D3 inhibits gamma-interferon synthesis by normal human peripheral blood lymphocytes. Proc Natl Acad Sci U S A 1987;84(10):3385-3389.

25. Kreindler JL, Steele C, Nguyen N, Chan YR, Pilewski JM, Alcorn JF, et al. Vitamin D3 attenuates Th2 responses to Aspergillus fumigatus mounted by CD4+ $\mathrm{T}$ cells from cystic fibrosis patients with allergic bronchopulmonary aspergillosis. J Clin Invest 2010; 120(9):3242-3254.

26. Black PN, Scragg R. Relationship between serum 25-hydroxyvitamin $\mathrm{d}$ and pulmonary function in the third national health and nutrition examination survey. Chest 2005;128(6):3792-3798.

27. Choi CJ, Seo M, Choi WS, Kim KS, Youn SA, Lindsey T, et al. Relationship between serum 25-hydroxyvitamin $\mathrm{D}$ and lung function among Korean adults in Korea National Health and Nutrition Ex- amination Survey (KNHANES), 2008-2010. J Clin Endocrinol Metab 2013;98(4):1703-1710.

28. Shaheen SO, Jameson KA, Robinson SM, Boucher BJ, Syddall HE, Sayer AA, et al. Relationship of vitamin D status to adult lung function and COPD. Thorax 2011;66(8):692-698.

29. Paul G, Brehm JM, Alcorn JF, Holguín F, Aujla SJ, Celedón JC. Vitamin D and asthma. Am J Respir Crit Care Med 2012;185(2):124132.

30. Ganji V, Zhang X, Tangpricha V. Serum 25-hydroxyvitamin D concentrations and prevalence estimates of hypovitaminosis $\mathrm{D}$ in the U.S. population based on assay-adjusted data. J Nutr 2012;142(3):498507.

31. Langlois K, Greene-Finestone L, Little J, Hidiroglou N, Whiting S. Vitamin D status of Canadians as measured in the 2007 to 2009 Canadian Health Measures Survey. Health Rep 2010;21(1):47-55.

32. Hilger J, Friedel A, Herr R, Rausch T, Roos F, Wahl DA, et al. A systematic review of vitamin $\mathrm{D}$ status in populations worldwide. $\mathrm{Br}$ J Nutr 2014;111(1):23-45.

33. Choi HS, Oh HJ, Choi H, Choi WH, Kim JG, Kim KM, et al. Vitamin D insufficiency in Korea: a greater threat to younger generation: the Korea National Health and Nutrition Examination Survey (KNHANES) 2008. J Clin Endocrinol Metab 2011;96(3):643651.

34. Lange NE, Litonjua A, Hawrylowicz CM, Weiss S. Vitamin D, the immune system and asthma. Expert Rev Clin Immunol 2009;5(6): 693-702. 